\title{
An overview of JIEM's second year, and a prospect of its third
}

\author{
Jose M Sallan, Mihaela Enache, Maria Albareda-Sambola, Vicenc Fernandez, Pep Simo \\ Universitat Politècnica de Catalunya (SP AIN) \\ jose.maria.sallan@upc.edu; mibaela.enache@upc.edu; maria.albareda@upc.edu; \\ vicenc.fernander@upc.edu; pep.simo@,upc.edu;
}

\begin{abstract}
This editorial honors the tradition established in the Journal of Industrial Engineering and Management (JIEM) since its inception, of presenting some relevant information about the evolution of JIEM during 2009, and about the future directions of the journal. We focus on issues concerning the quality of the journal (editorial board and reviewing process), prestige (progress on indexation), social responsibility and financial viability. We also provide information about the future evolution of JIEM, advancing the contents of the special issues planned for 2010 and 2011.
\end{abstract}

Keywords: JIEM, editorial, future directions

\section{Introduction}

With this editorial, we honor the tradition established in JIEM since its inception (Simo, Enache, Sallan \& Fernandez, 2009, Fernandez, Simo, Sallan \& Enache, 2008), of presenting some relevant and (we expect) interesting information about the evolution of JIEM during the past year to the journal stakeholders, and to the scientific community. This editorial states also our policy regarding the following years about issues such as the journal's social responsibility and financial viability.

The topics of this editorial cover the issues on which, according to Simo, GarciaParra, Sunyer, Trullas \& J orda (2006), must focus the editors of a scientific journal in its first years of publication: quality, prestige, social responsibility and financial viability. We will assess the journal quality giving information about the editorial board and the reviewing process, and about some features of the articles 
published. The prestige of a scientific journal comes from its indexation in databases of scientific information. Although JIEM has just reached its second year of life, we are proud to report some significant advances on that matter. The social responsibility of JIEM comes from being an open access journal. We believe that JIEM contributes to the advance of scientific knowledge in regions where the access to scientific information can become a scarce resource. Therefore we will report some data concerning the diffusion of JIEM throughout the world. For an open access journal, the question of financial viability is a relevant one. This editorial includes a statement of our present policy about JIEM funding. Finally, we conclude the editorial with some news concerning JIEM future issues.

\section{Journal quality: reviewing process and editorial team}

\subsection{Reviewing process}

As most academic journals, the editorial decisions in JIEM are grounded on the opinion of anonymous reviewers, following the usual peer-review process. In 2009, the editorial activity of JIEM can be summarized in the following figures: we received 85 manuscripts for review, of which 9 were rejected for being out of the editorial foci of interest of the journal. The remaining 76 manuscripts underwent the double-blind reviewing process. As a result, 48 were rejected and 28 were accepted for publication. Therefore, the rejection rate in 2009 is of the $67.06 \%$, if we consider all manuscripts submitted, or the $63.16 \%$, if we consider only the peer-reviewed manuscripts. Comparing to 2008, the number of manuscripts received has risen considerably (from 38 to 85 ), but the number of articles published has risen only slightly (from 23 to 28). To the 28 scientific articles published, we must add the two editorials (one in the first issue of 2008 and another in the special issue), to obtain the 30 items published in JIEM in 2009.

\subsection{I tems published}

As stated in the home page of its website, the aim of JIEM is to contribute to the advance of the Industrial Engineering and Management, in the following fields: Production, Logistics, Quality and Operational Research (PROD); Information Systems, Technology and Communication (IS); Industrial Economics and Regional Development (IND); Management, Organizational Behavior and Human Resources Management (MANAG); Finance, Accounting and Marketing in Industrial Sectors 
(FIN) and Education, Training and Professional Skills (EDUC). In addition to the two regular issues, with numbers 1 and 3, the number 2 of the 2009 volume is a special issue on the topic New Trends in Process Simulation and Modeling. In table 1 are summarized the number of articles published from each field in each of the three issues.

\begin{tabular}{|l|c|c|c|}
\hline \multicolumn{1}{|c|}{ Field } & Vol. 2, No. 1 & $\begin{array}{c}\text { Vol. 2, No. 2 } \\
\text { (Special I ssue) }\end{array}$ & Vol. 2, No. 3 \\
\hline Editorial & 1 & 1 & 5 \\
\hline PROD & 8 & & \\
\hline IS & 1 & & 3 \\
\hline IND & & & \\
\hline MANAG & 3 & & 1 \\
\hline FIN & 1 & & \\
\hline EDUC & 1 & 5 & $\mathbf{9}$ \\
\hline Special Issue & & $\mathbf{6}$ & \\
\hline Total & $\mathbf{1 5}$ & & \\
\hline
\end{tabular}

Table 1. "Items published in the Vol. 2 (2009) of JIEM, by field". Source: Editors

As can be seen in table 1, the Production field has been the most prolific one in JIEM during 2009. The present policy of JIEM is publishing in all fields related to Industrial Engineering and Management. Therefore, the editors encourage scholars working in the other fields different from Production and Operations Research to submit their manuscripts to JIEM.

\begin{tabular}{|l|c|l|c|}
\hline \multicolumn{1}{|c|}{ Country } & Authorships & \multicolumn{1}{c|}{ Country } & Authorships \\
\hline Spain & $31(43.66 \%)$ & Germany & $2(2.82 \%)$ \\
\hline USA & $9(12.68 \%)$ & Iran & $2(2.82 \%)$ \\
\hline Malaysia & $8(11.27 \%)$ & Singapore & $2(2.82 \%)$ \\
\hline India & $8(11.27 \%)$ & Thailand & $1(1.41 \%)$ \\
\hline Taiwan & $4(5.63 \%)$ & New Zealand & $1(1.41 \%)$ \\
\hline Finland & $3(4.23 \%)$ & \multicolumn{2}{l}{}
\end{tabular}

Table 2. "Authorships of items published in JIEM, by country of institution". Source: Editors

71 people authored the 30 items published in 2009. Three authors (Azman Ismail, Muhammad Madi Abdullah and Sebastian K. Francis) co-authored two of the papers published. As in 2008, Spain, the USA and Malaysia were the countries where worked most of the authors that published in JIEM. Authors worked in institutions of 11 different countries, spanning four continents. In table 2 we can find the complete list of countries of the institutions of authors work, together with the number of authorships of each country. In 2009, more than the $50 \%$ of authors worked in academic institutions outside of Spain. This fact consolidates the international character of JIEM. We hope to receive contributions from more countries in the future, in addition to the present ones. 


\subsection{Reviewers and editorial board}

Although the main responsibility (for good and for worse) of editorial decisions resides on the editorial team, we would like to thank the help and support of the editorial board, whose members have helped to foster the quality of the journal. The journal website reports the editorial team in the present moment. Therefore, in table 3 we have listed the members of the board in 2009. We have marked with an asterisk $(*)$ the members that joined the board in 2009. The present editorial board reflects the efforts undertaken through 2009 to make it more international, and to increase the number of women.

\begin{tabular}{|c|c|c|}
\hline Name & $\begin{array}{r}\text { Affiliation } \\
\end{array}$ & Country \\
\hline Ramon Companys Pascual & $\begin{array}{l}\text { Universitat Politècnica de } \\
\text { Catalunya }\end{array}$ & Spain \\
\hline Albert Corominas Subias & $\begin{array}{l}\text { Universitat Politècnica de } \\
\text { Catalunya }\end{array}$ & Spain \\
\hline Alysson M. Costa $(*)$ & Universidade de São Paulo & Brasil \\
\hline Anna Maria Coves Moreno $(*)$ & $\begin{array}{l}\text { Universitat Politècnica de } \\
\text { Catalunya }\end{array}$ & Spain \\
\hline María Victoria de la Fuente $(*)$ & $\begin{array}{l}\text { Universidad Politécnica de } \\
\text { Cartagena }\end{array}$ & Spain \\
\hline Isabel Fernández Quesada (*) & Universidad de Oviedo & Spain \\
\hline Eulàlia Griful Ponsati & $\begin{array}{l}\text { Universitat Politècnica de } \\
\text { Catalunya }\end{array}$ & Spain \\
\hline Ki-Young Jeong & University of Houston-Clear Lake & USA \\
\hline Luis López & INCAE & Costa Rica \\
\hline Amaia Lusa & $\begin{array}{l}\text { Universitat Politècnica de } \\
\text { Catalunya }\end{array}$ & Spain \\
\hline Cecilio Mar Molinero & $\begin{array}{l}\text { University of Kent - Kent } \\
\text { Business School }\end{array}$ & United Kingdom \\
\hline Silvia Miquel Fernández $(*)$ & Universitat de Lleida & Spain \\
\hline Josefa Mula $(*)$ & $\begin{array}{l}\text { Universidad Politécnica de } \\
\text { Valencia }\end{array}$ & Spain \\
\hline Rafael Pastor Moreno (*) & $\begin{array}{l}\text { Universitat Politècnica de } \\
\text { Catalunya }\end{array}$ & Spain \\
\hline Montserrat Pepió Viñals & $\begin{array}{l}\text { Universitat Politècnica de } \\
\text { Catalunya }\end{array}$ & Spain \\
\hline Eva Ponce $(*)$ & $\begin{array}{l}\text { Universidad Politécnica de } \\
\text { Madrid }\end{array}$ & Spain \\
\hline
\end{tabular}

Table 3. "List of members of JIEM editorial board in 2009 (Production, Logistics, Quality and Operational Research). Members added in 2009 are marked with asterisk". Source: editors.

\begin{tabular}{|l|l|l|}
\hline \multicolumn{1}{|c|}{ Name } & \multicolumn{1}{c|}{ Affiliation } & \multicolumn{1}{c|}{ Country } \\
\hline Josep Coll Bertran & $\begin{array}{l}\text { Universitat Politècnica de } \\
\text { Catalunya }\end{array}$ & Spain \\
\hline Amol Gore $\left(^{*}\right)$ & University of Mumbai & India \\
\hline Janni Nielsen & Copenhagen Business School & Denmark \\
\hline Joan Rodol Mòdol & ESADE & Spain \\
\hline José L. Salmerón & Universidad Pablo de Olávide & Spain \\
\hline Ana Suárez Sánchez $(*)$ & Universidad de Oviedo & Spain \\
\hline
\end{tabular}

Table 4. "List of members of JIEM editorial board in 2009 (Information Systems, Technology and Communication). Members added in 2009 are marked with asterisk". Source: editors. 


\begin{tabular}{|l|l|l|}
\hline \multicolumn{1}{|c|}{ Name } & \multicolumn{1}{c|}{ Affiliation } & \multicolumn{1}{c|}{ Country } \\
\hline Manuel Antonio Espitia Escuer & Universidad de Zaragoza & Spain \\
\hline Henry Etzkowitz & Newcastle University & United Kingdom \\
\hline Carlos Rodríguez Monroy & $\begin{array}{l}\text { Universidad Politécnica de } \\
\text { Madrid }\end{array}$ & Spain \\
\hline Francesc Solé Parellada & $\begin{array}{l}\text { Universitat Politècnica de } \\
\text { Catalunya }\end{array}$ & Spain \\
\hline Maria del Val Segarra Oña $\left(^{*}\right)$ & $\begin{array}{l}\text { Universidad Politécnica de } \\
\text { Valencia }\end{array}$ & Spain \\
\hline
\end{tabular}

Table 5. "List of members of JIEM editorial board in 2009 (Industrial Economics and Regional Development). Members added in 2009 are marked with asterisk". Source: editors.

\begin{tabular}{|l|l|l|}
\hline \multicolumn{1}{|c|}{ Name } & \multicolumn{1}{c|}{ Affiliation } & \multicolumn{1}{c|}{ Country } \\
\hline Marc Bonnet & $\begin{array}{l}\text { ISEOR (Université J ean Moulin } \\
\text { Lyon 3) }\end{array}$ & France \\
\hline Constantin Bratianu & Academy of Economic Studies & Romania \\
\hline Francisco Javier Carrillo & $\begin{array}{l}\text { Tecnológico de Monterrey } \\
\text { Universidad Peruana de Ciencias } \\
\text { Aplicadas }\end{array}$ & Mexico \\
\hline Pedro Castellano Masias $\left.*^{*}\right)$ & $\begin{array}{l}\text { Universitat Autònoma de } \\
\text { Barcelona }\end{array}$ & Spain \\
\hline Ercilia García Álvarez & Universitat Rovira i Virgili & Spain \\
\hline Azman Ismail & Universiti Malaysia Sarawak & Malaysia \\
\hline Pablo Martin de Holan & Instituto de Empresa & Spain \\
\hline Nelson Phillips & Imperial College & United Kingdom \\
\hline Lidia Puigvert & Universitat de Barcelona & Spain \\
\hline Lourdes Saiz $(*)$ & Universidad de Burgos & Spain \\
\hline Henri Savall & $\begin{array}{l}\text { ISEOR (Université J ean Moulin } \\
\text { Lyon 3) }\end{array}$ & France \\
\hline Ramón Valle Cabrera & Universidad Pablo de Olávide & Spain \\
\hline
\end{tabular}

Table 6. "List of members of JIEM editorial board in 2009 (Management, Organizational Behavior and Human Resources). Members added in 2009 are marked with asterisk". Source: editors.

\begin{tabular}{|l|l|l|}
\hline \multicolumn{1}{|c|}{ Name } & \multicolumn{1}{c|}{ Affiliation } & \multicolumn{1}{c|}{ Country } \\
\hline José António Almaça & $\begin{array}{l}\text { Universidade Autónoma de } \\
\text { Lisboa }\end{array}$ & Portugal \\
\hline Valentín Azofra Palenzuela & Universidad de Valladolid & Spain \\
\hline David Castillo & Universitat Oberta de Catalunya & Spain \\
\hline Francisco Martín Peña & Universitat de Barcelona & Spain \\
\hline Carme Martínez Costa & $\begin{array}{l}\text { Universitat Politècnica de } \\
\text { Catalunya }\end{array}$ & Spain \\
\hline Marta Mas Machuca $\left(^{*}\right)$ & $\begin{array}{l}\text { Universitat Politècnica de } \\
\text { Catalunya }\end{array}$ & Spain \\
\hline Lourdes Pérez & EADA & Spain \\
\hline Josep Maria Rosanas & IESE Business School & Spain \\
\hline Joan R. Tarradellas i Espuny & $\begin{array}{l}\text { Universitat Politècnica de } \\
\text { Catalunya }\end{array}$ & Spain \\
\hline Nidhi Walia $\left(^{*}\right)$ & Punjabi University & India \\
\hline
\end{tabular}

Table 7. "List of members of JIEM editorial board in 2009 (Finance, Accounting and Marketing in Industrial Sectors). Members added in 2009 are marked with asterisk". Source: editors. 


\begin{tabular}{|l|l|l|}
\hline \multicolumn{1}{|c|}{ Name } & \multicolumn{1}{c|}{ Affiliation } & \multicolumn{1}{c|}{ Country } \\
\hline Francisco Aliaga Abad & Universitat de València & Spain \\
\hline Juan A. Marín García & $\begin{array}{l}\text { Universitat Politècnica de } \\
\text { València }\end{array}$ & Spain \\
\hline Rafael Pindado Rico & $\begin{array}{l}\text { Universitat Politècnica de } \\
\text { Catalunya }\end{array}$ & Spain \\
\hline Cristina Poyatos Matas & Griffith University & Australia \\
\hline
\end{tabular}

Table 8. "List of members of JIEM editorial board in 2009 (Education, Training and Professional Skills). Members added in 2009 are marked with asterisk". Source: editors.

We would also like to thank the 91 anonymous reviewers that helped editors to asses the quality of manuscripts submitted to JIEM. JIEM editors may acknowledge, extending a certificate (upon request), the work of the reviewers that actively contributed to asses the manuscripts.

\subsection{Editorial team}

The four original members of the editorial team continued their task in 2009, and are still on duty in 2010: Mihaela Enache, Vicenc Fernandez, Jose M Sallan and Pep Simo. We are proud to announce that Maria Albareda has joined the editorial team in 2009. Maria currently works at the Department of Statistics and Operational Research at the Universitat Politècnica de Catalunya. She is a graduate in Mathematics for the Universitat Politècnica de Catalunya, and received her Ph. D. in the same institution. Her main research interests are heuristic methods and linear integer programming models for combinatorial problems, particularly with application to vehicle routing and discrete facility location and other logistic problems.

We would also like to thank José Luis Salmerón for serving as guest editor of the first Special Issue of JIEM on New Trends of Process Simulation and Modeling. José Luis works currently as professor of Information Systems at the Universidad Pablo de Olavide in Seville (Spain).

\section{Prestige and indexing}

The main indicator of prestige of a scholarly journal is its indexation in bibliographic databases. Such databases foster the visibility of the journal, putting its content together and facilitating its consultation to academics and to the public. Bibliographic databases can also provide indicators of quality, such as the impact factor. Since the impact factor is usually computed from the citations received in 
the last two or four years, JIEM is a journal too young to be indexed in citation databases. Nevertheless, in spite of its youth, JIEM has been indexed in several prestigious databases during 2009. The updated list can be obtained from the URL address http://jiem.org/index.php/jiem/about/editorialPolicies\#custom0. In 2009, JIEM was indexed in:

- Cabells Directory

- CrossRef

- EPFL (École Polytechnique Fédérale de Lausanne Library)

- e-Revistas (Plataforma Open Access de Revistas Científicas Electronicas Españolas y Latinoamericanas)

- Dialnet (Universidad de La Rioja, Spain)

- DOAJ (Directory of Open Access J ournals)

- Dulcinea

- OASPA (Open Access Scholarly Publishers Association)

- OJS Journal List

- Open Science Directory

- RACO (Revistes Catalanes amb Accés Obert)

- Ulric's Periodicals Directory

- UPC Bibliotècnica

- UPCommons

We will continue working on indexing JIEM in databases useful for its readers and authors. We encourage JIEM readers to suggest databases where JIEM can be indexed in the near future. 


\section{Social responsibility and financial viability}

\subsection{Open access policy}

One of the reasons that moved us to create JIEM is that the current academic editorial system, mainly grounded on journals accessible only to the institutions and particulars with the financial capability to spend the huge subscription fees that give access to relevant scientific information, hinders the effectiveness of the scientific publication system, and also of the scientific system as a whole (Sallan, Simo and Garcia-Parra, 2006). Consistently with this belief, JIEM is published as an open access journal, and at the present time (July of 2010) does not charge fees to authors for publishing its work. The JIEM website has received an average traffic of 202.13 sessions per day, and its contents can be downloaded freely worldwide through the journal website, and through repositories such as UPCommons or Dialnet.

At the present time, JIEM is supported by the work of authors, reviewers, editorial board and editorial team. In 2009, JIEM has received financial support from the Universitat Politècnica de Catalunya - Barcelona Tech.

\subsection{Printed edition}

Some authors and readers of JIEM have asked us to publish a printed edition of the journal. Although we rejected this possibility in the first moment, the development of printing-on-demand services has made possible to publish a printed edition of each of the issues of JIEM at a reasonable price. Given the costs of publishing JIEM on paper, the printed editions are not free. The online edition of each of the articles, which is the main source of diffusion of JIEM, continues to be open access.

In the URL address http://jiem.org/index.php/jiem/about/editorialPolicies\#custom1 can be found the links that lead to the available printed editions.

\subsection{Equality between men and women}

The quest for equality for men and women in academy is other of the aims that lead JIEM social responsibility. We have tried to comply with our commitment of increasing the number of women in JIEM editorial board, as intended in Simo et al. (2009). In 2010, we have posted the call for papers for a special issue on Gender 
Issues in Industrial Engineering and Management (see below for more details). We also encourage the submission of manuscripts for the regular issues covering gender issues, especially (but not exclusively) in the field of Management, Organizational Behavior and Human Resources Management.

\section{Future directions: a prospect of the third year of JIEM}

The evolution of JIEM in its second year has confirmed the priorities that we established in the 2008 editorial (Simo et al., 2009). The future of JIEM will depend on our ability to continue working in the following directions:

Assuring a rigorous and informed anonymous, peer-reviewed process to select the contributions to be published in JIEM.

Continue the process of indexing JIEM in relevant scientific databases. This is a slow process, where targets can only be set in the medium term, but it is the best way to foster the visibility of the published articles, and to attract good scholarly and scientific work in the future.

A good editorial board is one of the most valued assets that a scientific journal can hold. We must continue working to reinforce the board in all the fields of interest of JIEM. We are also committed to increase the number of women of the board, following the trend set in 2009.

Another way to attract authors to JIEM is the publication of special issues. In this moment, we have planned three special issues. Two of them consist of the publication of the best papers of two Industrial Engineering conferences: MOSTP 2010 and ICOVACS 2010. We have also placed a call of papers on the subject Gender Issues in Industrial Engineering and Management. The guest editors are Amaia Lusa and Carme Martinez, and the deadline for the submission of manuscripts is January $1^{\text {st }}, 2011$. We encourage authors to contribute to this special issue, and also to the regular issues of the journal.

\section{References}

Fernandez, V., Simo, P., Sallan, J. M., \& Enache, M. (2008). JIEM: A new exciting journey into the research of industrial engineering and management. Journal of 
Industrial Engineering and Management, 1(1), 1-3.

doi: 10.3926/jiem.2008.v1n1.p1-3

Sallan, J. M., Simo, P., Garcia-Parra, M. (2006). From the editors: the present and future of the scientific communication system. Intangible Capital, 2(2), 181-198.

Simo, P., Enache, M., Sallan, J. M., Fernandez, V. (2009). First year reflections: Basic Guidelines and future directions. Journal of Industrial Engineering and Management, 2(1), 1-9. doi: 10.3926/jiem.2009.v2n1.p1-9

Simo, P., Garcia-Parra, M., Sunyer, S., Trullas, G., Jorda, J. M. (2006). From the editors: An assessment of open access journals: quality, prestige and social responsibility. Intangible Capital, 2(1), 1-20.

(c) Journal of Industrial Engineering and Management, 2010 (www.jiem.org)

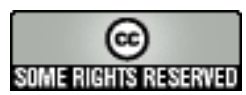

Article's contents are provided on a Attribution-Non Commercial 3.0 Creative commons license. Readers are allowed to copy, distribute and communicate article's contents, provided the author's and Journal of Industrial Engineering and Management's names are included. It must not be used for commercial purposes. To see the complete license contents, please visit http://creativecommons.org/licenses/by-nc/3.0/. 